\title{
PENGARUH SENAM ZUMBA TERHADAP JUMLAH TROMBOSIT PADA MAHASISWA FAKULTAS KEDOKTERAN UNIVERSITAS SAM RATULANGI
}

\author{
${ }^{1}$ Yohanes Tjandra \\ ${ }^{2}$ Jouri Rampengan \\ ${ }^{2}$ Siantan Supit

\begin{abstract}
${ }^{1}$ Kandidat Skripsi Fakultas Kedokteran Universitas Sam Ratulangi Manado
${ }^{2}$ Bagian Fisiologi Fakultas Kedokteran Universitas Sam Ratulangi Manado Email: tjanjoe@gmail.com
\end{abstract}

\begin{abstract}
Various studies show that sufficient physical activity can reduce the risk of obesity, diabetes and heart disease and vascular disorders. There are two types of sports activities, namely: anaerobic and aerobic. Gymnastics zumba combines elements of dance and aerobics. Gymnastics zumba is a form of application of the method of HIIT (High Intensity Interval Training), which cardio exercise is done in a short time with a high intensity; so, it is very helpful in the process of fat burning and weight loss. Conclusion: Based on the paired t test results, there was no significant difference in platelet count between pretest and posttest $(\mathrm{p}=$ $0.654)$.
\end{abstract}

Keywords: platelets, gymnastics zumba

\begin{abstract}
Abstrak: Berbagai penelitian menunjukkan aktivitas fisik yang cukup dapat mengurangi risiko obesitas, diabetes dan penyakit jantung serta gangguan pembuluh darah. Ada dua jenis aktivitas olahraga, yaitu: anaerobik dan aerobik. Senam zumba menggabungkan unsur tari dan aerobik. Senam zumba merupakan bentuk penerapan dari metode HIIT (High Intensity Interval Training), yakni latihan kardio yang dilakukan dalam waktu singkat dengan intensitas yang tinggi, sehingga sangat membantu dalam proses pembakaran lemak dan penurunan berat badan. Simpulan: Berdasarkan hasil uji t berpasangan maka disimpulkan tidak terdapat perbedaan jumlah trombosit yang bermakna antara pretest dan posttest $(\mathrm{p}=0,654)$.
\end{abstract}

Kata kunci: trombosit, senam zumba

Aktivitas fisik merupakan gerakan-gerakan yang dilakukan oleh otot rangka yang membutuhkan energi. ${ }^{1}$ Ada dua jenis aktivitas olahraga, yaitu: anaerobik dan aerobik. Istilah aerobik dan anaerobik berhubungan dengan perbedaan cara tubuh menghasilkan energi. Perbedaan itu meliputi penggunaan oksigen. Oksigen digunakan oleh tubuh kita untuk memecah karbohidrat dan mengubahnya menjadi energi saat kita beristirahat. ${ }^{2}$

Senam zumba termasuk dalam jenis fitness yang terinspirasi dari tarian latin. Senam zumba menggabungkan unsur tari dan aerobik. $^{3}$ Senam zumba sendiri diciptakan oleh seorang dancer dan koreografer bernama Alberto "Beto" Perez yang berkolaborasi dengan dua orang entrepeneur yakni Alberto Perlman dan Alberto Aghion pada tahun 1990. Senam Zumba mulai dikenalkan di Indonesia pada tahun 2001 oleh Alberto "Beto" Perez sendiri. Gerakan senam zumba terdiri dari berbagai variasi tarian bergaya Latin yang menggabungkan unsur tarian lain seperti, meringue, pop, reggaeton, cumbia, mambo, salsa, flamenco, rumba, dan calypso. Kombinasi latihan squat dan lunges juga 
banyak diterapkan dalam senam ini. Senam zumba bisa dilakukan dalam tempo yang cepat dan lambat, sehingga dapat terhindar dari kebosanan, memiliki gerakan yang lebih lincah, dan lebih banyak otot yang bekerja. Senam ini merupakan bentuk penerapan dari metode HIIT (High Intensity Interval Training), yakni latihan kardio yang dilakukan dalam waktu singkat dengan intensitas tinggi, sehingga sangat membantu dalam proses pembakaran lemak dan penurunan berat badan. ${ }^{4}$

Trombosit berjumlah 150.000 sampai 450.000 per $\mathrm{mm}^{3}$. Ukuran trombosit mencapai setengah ukuran sel darah merah. Sitoplasmanya terbungkus suatu membran plasma dan mengandung berbagai jenis granula yang berhubungan dengan proses koagulasi darah. Trombosit berfungsi dalam hemostasis (penghentian perdarahan) dan perbaikan pembuluh darah yang robek. $^{5}$ Trombosit berumur kira-kira 10 hari dalam darah. Trombosit dibuang oleh sel-sel fagosit dalam limpa. Normalnya waktu terobosan dalam endotelium kapiler dengan cepat ditutup oleh kerja trombosit. ${ }^{6}$

Hasil dari beberapa penelitian mengidentifikasikan peningkatan trombosit sebesar $18-80 \%$ segera setelah melakukan latihan treadmill. Besarnya jumlah penambahan trombosit dengan latihan sesaat dipengaruhi oleh beratnya latihan.

Penelitian lain menunjukkan adanya peningkatan kadar katekolamin, peningkatan adenosine dipospat (ADP) dan peningkatan tromboxan $A 2$ setelah latihan fisik yang dapat menyebabkan perubahan pada aktivasi trombosit. Peneliti lain membuktikan bahwa ada pengaruh latihan aerobik intesitas sedang terhadap peningkatan jumlah trombosit pada remaja putri di Universitas Prima Indonesia. ${ }^{7}$

Tujuan penelitian ini untuk mengetahui pengaruh senam zumba terhadap jumlah trombosit pada mahasiswa Fakultas Kedokteran Universitas Sam Ratulangi.

\section{METODE PENELITIAN}

Penelitian ini bersifat eksperimental laboratorik yang mengikuti rancangan randomized pre-test dan post-test group design selama satu minggu. Penelitian dilakukan di Aula Fakultas Kedokteran Kampus Malalayang selama satu minggu pada bulan Desember 2014.

Populasi penelitian ialah mahasiswa Fakultas Kedokteran Universitas Sam Ratulangi angkatan 2014. Jumlah sampel yang diambil 18. Pemilihan sampel menggunakan metode purposive sampling sesuai dengan kriteria inklusi. Kriteria inklusi, bersedia menjadi subjek penelitian, berusia antara 17-19 tahun, dan dalam keadaan sehat. Pemeriksaan jumlah trombosit dilakukan hari pertama sebelum senam zumba dimulai dan setelah senam zumba selesai pada hari ke tujuh.

Pemeriksaan darah subjek penelitian dilakukan petugas laboratorium. Darah untuk pemeriksaan diambil secara intravena (IV) pada vena mediana cubiti. Sampel darah sebelum latihan diambil pada hari pertama dimulai latihan, sebelum aktivitas senam zumba dilakukan. Darah diambil sebanyak 3 cc dengan menggunakan spuit $5 \mathrm{cc}$, selanjutnya darah ditampung ke dalam tabung vacutainer EDTA $0.5 \mathrm{mg}$, selanjutnya tabung digoyang pelan agar tercampur merata dengan EDTA yang ada di dalam tabung. Setelah selesai pengambilan sampel darah, tabung dimasukkan ke dalam wadah tertutup dan segera dibawa ke Laboratorium.

Pengambilan sampel darah yang kedua yaitu sesudah aktivitas senam zumba dilakukan pada hari terakhir latihan, segera setelah subjek penelitian menyelesaikan latihan. Pengambilan darah sebanyak 3cc dengan menggunakan spuit 5 cc, dan ditampung di tabung vacutainer EDTA 0.5 mg. Selanjutnya tabung tersebut dimasukkan kedalam wadah tertutup dan segera dibawa ke Laboratorium untuk dilakukan pemeriksaan jumlah trombosit. Trombosit darah diperiksa dengan menggunakan alat haematology cell counter. Alat ini akan bekerja secara otomatis setelah sampel darah dimasukkan, hasil akan keluar \pm 2 menit kemudian. Sebelum sampel darah dimasukkan ke dalam alat haematology cell counter 
terlebih dahulu sampel darah dihomogenkan dengan cara menggoyang tabung vacutainer.

\section{HASIL PENELITIAN}

Berdasarkan hasil penelitian yang dilakukan terhadap Mahasiswa Fakultas Kedokteran Universitas Sam Ratulangi Manado angkatan 2014 diperoleh data yang disajikan dalam bentuk tabel distribusi.

\section{Karakteristik Fisik Subyek}

Subyek penelitian 18 orang merupakan mahasiswa Fakultas Kedokteran Universitas Sam Ratulangi, perempuan, berusia 17-19 tahun, berbadan sehat, IMT normal, bukan merupakan altet dan baru pertama kali mengikuti senam zumba.

Tabel 1. Karakteristik Subyek

\begin{tabular}{lcc}
\hline & Nilai & Rerata \\
& kisaran & \\
\hline Umur (tahun) & $17-19$ & 18,25 \\
Tinggi Badan (cm) & $151-168$ & 158,10 \\
Berat Badan (kg) & $20,10-$ & 23,33 \\
& 26,72 & \\
IMT $\left(\mathrm{kg} / \mathrm{m}^{2}\right)$ & $18,47-$ & 20,68 \\
& 21,82 & \\
\hline
\end{tabular}

Jumlah Trombosit

Hasil analisis statistik menunjukkan data nilai jumlah trombosit pada kelompok sebelum melakukan senam zumba dan kelompok sesudah melakukan senam zumba. Perbandingan nilai rerata jumlah trombosit sebelum senam terlihat pada Tabel 2. Hasil analisis statistik menunjukkan nilai rerata jumlah trombosit setelah senam zumba meningkat dari sebelum melakukan senam zumba yakni $289,9410^{3} / \mathrm{mm}^{3}$.

Tabel 2. Karakteristik Rerata Jumlah Trombosit Sebelum dan Sesudah Senam Zumba

\begin{tabular}{cc}
\hline Trombosit & Rerata $\left(10^{3} / \mathrm{mm}^{3}\right)$ \\
\hline Sebelum & 283,00 \\
\hline Sesudah & 289,94 \\
\hline
\end{tabular}

\section{BAHASAN}

Hasil analisis pada penelitian ini secara statistik dengan menggunakan SPSS tidak terdapat perubahan $(\mathrm{p}=0,654)$. Berbeda secara presentase mengalami peningkatan jumlah trombosit rata-rata sekitar 2,54\%.

Penelitian yang dilakukan oleh ElSayed et al. menunjukkan bahwa latihan atau olahraga terbukti mempengaruhi peningkatan jumlah trombsit dalam darah. ${ }^{8}$ Berdasarkan teori yang ada menyatakan bahwa peningkatan jumlah trombosit di dalam tubuh dipengaruhi oleh faktor kesehatan seseorang, ketinggian tempat tinggal seseorang dari permukaan laut. Kondisi kesehatan yang dapat mempengaruhi tingginya kadar trombosi dalam darah (trombositosis) yaitu: alergi, aspyksia, perdarahan, patah tulang dan trauma. Kondisi kesehatan yang dapat menyebabkan rendahnya kadar trombosit dalam darah (trombositopenia) yaitu infeksi akut, leukemia akut, splenomegali, typoid, dan TBC. ${ }^{9}$

\section{DAFTAR PUSTAKA}

1. Aktivitas. Definisi aktivitas Available from URL:

http://www.bimbingan.org/definisiaktivitas.htm

2. Olah tubuh. Aerobik, anaerobik. Available from URL

http://readersdigest.co.id/sehat/olah.tu buh/aerobik.atau.anaerobik/005/003/5 3

3. Zumba (2013). Zumba Aerobik. Available from URL: http://megapolitan.kompas.com/read/ 2011/12/14/15033133/5

4. Senam Zumba. Membakar lemak 2012. Available from URL :http://duniafitnes.com/fitness-forwomen/asyiknya-membakar-lemakdengan-senam-zumba.html

5. Sloane E. Anatomi dan Fisiologi untuk Pemula. Edisi ke-. Jakarta: EGC; 2004. p.224

6. Cambridge C. Anatomi Fisiologi Sistem Pernapasan dan Sistem Kardiovaskular. Edisi ke-2. Jakarta: EGC; 2009.

7. Lister. Pengaruh Latihan Aerobik Intensitas Ringan dan Sedang terhadap Jumlah 
Tjandra, Rampengan, Supit: Pengaruh senam zumba...

Trombosit pada Remaja Putri di Universitas Prima Indonesia. USU eRepository: Tesis; 2008.

8. El-Sayed, Mahmoud, Nagia, Zeinab. 2005. Aggregation and Activation of Blood Platelets in Exercise and Training. Available from : http://www.ncbi.nlm.nih.gov/pubmed $/ 15651910$

9. Sembulingan $K$, Sembulingan $P$. Essentials of Medical Physiology, Jaypee Brothers, Medical Publisers (P) LTD, New Delhi, India 